\title{
Bacillus pumilus laccase: a heat stable enzyme with a wide substrate spectrum
}

Renate Reiss, Julian Ihssen, Linda Thöny-Meyer ${ }^{*}$

\begin{abstract}
Background: Laccases are multi-copper oxidases that catalyze the one electron oxidation of a broad range of compounds. Laccase substrates include substituted phenols, arylamines and aromatic thiols. Such compounds are activated by the enzyme to the corresponding radicals. Owing to their broad substrate range laccases are considered to be versatile biocatalysts which are capable of oxidizing natural and non-natural industrial compounds, with water as sole by-product.

Results: A novel CotA-type laccase from Bacillus pumilus was cloned, expressed and purified and its biochemical characteristics are presented here. The molecular weight of the purified laccase was estimated to be $58 \mathrm{kDa}$ and the enzyme was found to be associated with four copper atoms. Its catalytic activity towards 2,2'-azino-bis(3ethylbenzthiazoline-6-sulphonic acid) (ABTS), 2,6-dimethoxyphenol (2,6-DMP) and syringaldazine (SGZ) was investigated. The kinetic parameters $K_{M}$ and $k_{\text {cat }}$ for ABTS were $80 \pm 4 \mu \mathrm{M}$ and $291 \pm 2.7 \mathrm{~s}^{-1}$, for 2,6-DMP $680 \pm 27$ $\mu \mathrm{M}$ and $11 \pm 0.1 \mathrm{~s}^{-1}$ and for SGZ only $k_{\text {cat }}$ could be estimated to be $66 \pm 1.5 \mathrm{~s}^{-1}$. The pH optimum for ABTS was 4, for 2,6-DMP 7 and for SGZ 6.5 and temperature optima for ABTS and 2,6-DMP were found to be around $70^{\circ} \mathrm{C}$. The screening of 37 natural and non-natural compounds as substrates for B. pumilus laccase revealed 18 suitable compounds. Three of them served as redox mediators in the laccase-catalyzed decolorization of the dye indigocarmine (IC), thus assessing the new enzyme's biotechnological potential.
\end{abstract}

Conclusions: The fully copper loaded, thermostable CotA laccase from Bacillus pumilus is a versatile laccase with potential applications as an industrial biocatalyst.

\section{Background}

Laccases (EC 1.10.3.2), together with ferroxidases (EC 1.16.3.1), ascorbate oxidase (EC 1.10.3.3) and ceruloplasmin (EC 1.16.3.1) belong to the multi-copper oxidase (MCO) enzyme family. These enzymes are classified as blue copper proteins and contain between one and six copper atoms. They are produced by various fungi, plants, insects and bacteria [1]. They catalyze the oxidation of a range of organic substances via a four-electron reduction of oxygen to water $[2,3]$.

Laccase catalyzed reactions include the polymerization of monomers, degradation of polymers and the oxidation of phenolic compounds [4]. Laccases can act on non-phenolic compounds by employing mediators, which undergo an oxidation-reduction cycle, thus shuttling electrons between the non-phenolic compound and

\footnotetext{
* Correspondence: linda.thoeny@empa.ch

Empa, Swiss Federal Laboratories for Materials Science and Technology, Laboratory for Biomaterials, Lerchenfeldstr.5, 9014 St. Gallen, Switzerland
}

the enzyme. These laccase mediator systems (LMS) have been used in a number of processes including pulp delignification and oxidation of organic pollutants [5].

Besides being commercially used in denim bleaching, laccases have also been applied in the decolorization and transformation of textile dyes. Dye effluents from the textile industry represent a major environmental pollutant, and conventional degradation processes suffer from inefficiency, are not price competitive or result in toxic by-products [6-9].

Numerous studies have shown that laccase catalyzed decolorization of textile dyes was achieved either by direct oxidation or via indirect oxidation using mediators, which enhanced or enabled the reaction $[7,10]$. Preferably, mediators should be good laccase substrates, stable in oxidized and reduced form and have no inhibitory effect upon enzyme activity. Once oxidized, mediators interact between the active site of the enzyme and the target molecule, thus broadening the range of 
substrates which can be oxidized. Well established non-natural laccase mediators are ABTS, TEMPO (2,2,6,6-tetramethyl-piperidine-1-oxyl radical) and HBT (1-hydroxybenzotriazole). However, the emphasis on natural mediators has gained momentum due to economic and ecological awareness [11,12].

To date, only fungal laccases are industrially relevant for the detoxification of synthetic dyes and other applications owing to their higher redox potential compared to bacterial laccases [4,5,13-16]. However, more recently bacterial laccases have also been shown to successfully oxidize dyes in the presence and absence of redox mediators [17-19]. Developing bacterial laccases for biotechnological applications will be advantageous because they are sustainable and can be produced in a short time in inexpensive media. Fungal laccases suffer from several drawbacks, such as lack of functional or efficient expression in heterologous hosts, relatively long fermentation times and comparatively low yield. Furthermore, as bacterial laccases are suitable for heterologous expression in $E$. coli, the enzyme can easily be tailored using techniques such as directed evolution [20]. Based on the intrinsic properties of bacterial laccases, these enzymes have great potential as biocatalysts for oxidation reactions, as they operate in aqueous solvent at neutral to basic $\mathrm{pH}$, are temperature stable, cofactor-independent and produce water as a sole by-product [21].

The endospore coat protein CotA from Bacillus subtilis is a well-studied thermostable bacterial laccase which has been crystallized. It is believed to play a role in the biosynthesis of the brown spore pigment, which might be involved in the UV light protection of the spore coat [22]. CotA contains a four-copper active site with the type 1 blue copper centre T1 and the T2/T3 trinuclear cluster (one type 2 and two type 3 copper atoms) $[22,23]$. The one electron oxidation of the substrate to the corresponding radical takes place at the $\mathrm{T} 1$ site and the abstracted electron is transferred to the trinuclear centre, where dioxygen is reduced to water [24]. Other bacterial laccases have been described in Azospirillum lipoferum, Escherichia coli, Bacillus licheniformis, Bacillus halodurans, Streptomyces coelicolor, Thermus thermophilus and $\gamma$-Proteobacterium $J B$, to mention the most relevant examples $[4,19,25]$. Bacterial laccases are characterized by their high temperature tolerance and high levels of activity in neutral to alkaline conditions, whereas fungal laccases usually operate under acidic $\mathrm{pH}$.

We have identified a CotA-type laccase from Bacillus pumilus by genome mining which differed by over $30 \%$ in its amino acid sequence from the B. subtilis laccase. We cloned the corresponding gene, purified the protein and characterized it biochemically. The purified laccase was tested for its ability to decolorize indigocarmine (IC), a compound belonging to the group of carbonyl dyes which are widely used in the industrial production of denim. The decolorization of this dye remains challenging and enzymatic decolorization using the laccase directly or as LMS has great potential.

\section{Methods \\ Materials}

2,2'-Azino-bis(3-ethylbenzthiazoline-6-sulphonic acid) (ABTS), 4-hydroxy-3,5-dimethoxybenzaldehyde azine (syringaldazine, SGZ), 2,6-dimethoxyphenol (2,6-DMP), 3', 5'-dimethoxy-4'-hydroxyacetophenone (acetosyringone $(\mathrm{ACS})$ ) and indigocarmine (IC) were purchased from Sigma-Aldrich. All other chemicals were standard reagent grade (Sigma Aldrich).

\section{Bacterial strains and plasmids}

B. pumilus DSM 27 was obtained from the German collection of microorganisms (DSMZ). E. coli strain JM109 [genotype endA1 recA1, gyrA96, thi, hsdR17, $\left(\mathrm{r}_{\mathrm{K}}{ }^{-}, \mathrm{m}_{\mathrm{K}}{ }^{+}\right)$, relA $1, \sup E 44, \lambda^{-}, \Delta($ lac-pro $A B)$, (F', traD36, pro $A B$, lacI $\left.\left.{ }^{\mathrm{q}} \mathrm{Z} \Delta \mathrm{M} 15\right)\right]$ and the $\mathrm{pQE}-60$ expression vector were purchased from Promega (Madison, USA) and Qiagen (Valencia, USA), respectively. The origin of replication in pQE-60 is ColE1 (pBR322) and transcription of the inserted gene is controlled by the bacteriophage T5 promoter (recognized by the E. coli housekeeping RNA polymerase) and two lac operator sequences (conferring inducibility by IPTG). For efficient repression the host strain JM109 which over-expresses the repressor LacI was used.

B. pumilus was grown overnight at $30^{\circ} \mathrm{C}$ and $150 \mathrm{rpm}$ in SRB medium $(20 \mathrm{~g} / \mathrm{L}$ yeast extract

$25 \mathrm{~g} / \mathrm{L}$ tryptone, $\left.3 \mathrm{~g} / \mathrm{L} \mathrm{K}_{2} \mathrm{HPO}_{4}\right)$. E. coli was routinely grown in $\mathrm{LB}$ medium at $37^{\circ} \mathrm{C}$ and $150 \mathrm{rpm}$. For plasmid selection $0.1 \mathrm{mg} / \mathrm{mL}$ ampicillin was added to LB agar plates and liquid medium.

\section{Cloning of the $B$. pumilus laccase gene}

The putative laccase gene (spore coat protein $\mathrm{A}, \cot A)$ of $B$. pumilus was identified by Protein Blast (http://blast.ncbi.nlm.nih.gov/Blast.cgi) using the CotA sequence of $B$. subtilis as search template (gene bank accession no. NP_388511). The cotA gene of B. pumilus (accession no. ZP_03054403) was PCR amplified from genomic DNA with forward primer 5'- CGT CC ATG GAA AAC CTA GAA AAA TTT GTT GAC GAG C -3' (introducing an $\mathrm{NcoI}$ site around the native start codon and an additional glutamate codon after ATG) and reverse primer 5'- CCATG AAGCTT TTA CTG GAT GAT ATC CAT CGG C-3' (introducing a HindIII site after the native stop codon). PCR was performed with high fidelity Phusion polymerase (New England Biolabs, Ipswich, USA) and appropriately diluted cell suspension of B. pumilus DSM 27 as template. The 1552 
bp PCR product was cloned into the high copy number cloning vector pJet/Blunt (Fermentas, St. Leon-Rot, Germany) by blunt end ligation. After sequence verification the 1542 bp NcoI-cotA-HindIII fragment of pJet/Blunt-cotA was sub-cloned into the NcoI and Hin$d$ III sites present in the multiple cloning site of pQE60 , resulting in plasmid pBpL2. The NcoI site of pQE60 contains the start codon for expression of cloned genes. In order to obtain fully wild-type CotA of $B$. pumilus the additional glutamate codon introduced at position 2 for cloning purposes was removed from pBpL2 by quick change mutagenesis using forward primer 5'-GAGGAGAAATTAACC ATG AAC CTA GAA AAA TTT GTT GAC-3' and complementary reverse primer 5'-GTC AAC AAA TTT TTC TAG GTT CAT GGTTAATTTCTCCTC-3'. A map of the final expression plasmid pBpL6 containing the $\cot A$ gene as confirmed by DNA sequencing is shown in the Additional file 1.

\section{CotA production}

E. coli JM109 was transformed with pBpL6 for expression and purification of $B$. pumilus laccase.

To obtain a fully copper loaded enzyme, the method reported by Durao et al. 2008 was used for CotA production [26]. Briefly, the recombinant $E$. coli strain was cultivated in TB medium supplemented with $0.1 \mathrm{mg} / \mathrm{mL}$ ampicillin at $30^{\circ} \mathrm{C}$ and $120 \mathrm{rpm}$. Starting from an isolated colony, an overnight pre-culture was diluted 1:50 into a $700 \mathrm{~mL}$ volume in a $2 \mathrm{~L}$ Erlenmeyer flask. At an optical density of $1-2\left(\Delta \mathrm{OD}_{600}\right)$, laccase expression was induced by adding $0.1 \mathrm{mM}$ IPTG. At the same time, $0.25 \mathrm{mM} \mathrm{CuCl}_{2}$ was added and the temperature was decreased to $25^{\circ} \mathrm{C}$. The cells were further incubated for $4 \mathrm{~h}$ at $120 \mathrm{rpm}$ and then without shaking for additional 16 hours. Durao et al. (2008) showed that static incubation improved the cellular copper content, thus yielding a fully copper loaded protein population. Cells were harvested by centrifugation at $4^{\circ} \mathrm{C}$ for $30 \mathrm{~min}$ at $4,495 \times g$, washed in $20 \mathrm{mM}$ Tris buffer $\mathrm{pH} 7.6$, centrifuged again and subsequently stored at $-20^{\circ} \mathrm{C}$

Frozen cells were thawed on ice and resuspended in $20 \mathrm{mM}$ Tris buffer pH 7.6 containing $1 \mathrm{mg} / \mathrm{mL}$ lysozyme and protease inhibitor mix (Roche Complete Protease Inhibitior Mix, EDTA-free) and re-frozen at $-80^{\circ} \mathrm{C}$. Cells were thawed, Benzonase ${ }^{\circledR}$ Nuclease (Roche) was added and the suspension incubated for $1 \mathrm{~h}$ at $37^{\circ} \mathrm{C}$ at $120 \mathrm{rpm}$. The suspension was subjected to twelve $10 \mathrm{~s}$ rounds of sonication with a Branson sonicator equipped with a microtip at a setting of $80 \%$. Cellular debris was removed by centrifugation at $4^{\circ} \mathrm{C}$ for $40 \mathrm{~min}, 47,000 \times g$. The crude cell lysate was incubated at $70^{\circ} \mathrm{C}$ for $20 \mathrm{~min}$ and soluble protein was collected by centrifugation at $4^{\circ} \mathrm{C}$ for $40 \mathrm{~min}$ and $47,000 \times g$. Purification was performed on an
Äkta purifier FPLC system (GE-Healthcare). The sample was loaded onto a $27 \mathrm{~mL}$ Q-Sepharose FF anion exchange chromatography column (GE-Healthcare), previously equilibrated with $20 \mathrm{mM}$ Tris buffer $\mathrm{pH}$ 7.6. Proteins were eluted with a $\mathrm{NaCl}$ gradient from 0 to $1 \mathrm{M}$. Fractions displaying laccase activity, as detected using an ABTS oxidation assay, were pooled and concentrated by ultrafiltration using a $30 \mathrm{kDa}$ cut-off. The sample was loaded onto a Superdex 75 column (GE-Healthcare), previously equilibrated with $20 \mathrm{mM}$ Tris buffer containing $0.1 \mathrm{M} \mathrm{NaCl} \mathrm{pH} \mathrm{7.6.} \mathrm{Fractions} \mathrm{with} \mathrm{laccase} \mathrm{activity} \mathrm{were}$ pooled, concentrated by ultrafiltration and stored in $20 \mathrm{mM}$ Tris buffer $\mathrm{pH} 7.6$ at $-80^{\circ} \mathrm{C}$. The purity of the sample was analyzed by SDS-PAGE using a $10 \%$ polyacrylamide gel. The copper content was determined by ICP-OES (Inductive coupled plasma optical emission spectroscopy) on a Perkin Elmer Optima 3000 instrument. The protein solution was treated with nitric acid in a microwave digestion system prior to optical analysis at $\mathrm{Cu}$ lines $327.393 \mathrm{~nm}$ and $324.752 \mathrm{~nm}$.

\section{Determination of protein and enzyme activities}

Total protein concentration was determined by the method of Bradford [27] with bovine serum albumin (BSA) as standard and by UV-Vis absorbance measurements with a Nanodrop ND-1000 spectrophotometer using an extinction coefficient of $77,303 \mathrm{M}^{-1} \mathrm{~cm}^{-1}$ (calculated from the amino acid sequence).

Spectrophotometric laccase activity assays were routinely carried out in a 96 -well plate at $25^{\circ} \mathrm{C}$ with $0.5 \mathrm{mM}$ ABTS in McIlvaine buffer at $\mathrm{pH} 4$ (mixture of $0.1 \mathrm{M}$ citric acid and $0.2 \mathrm{M} \mathrm{K}_{2} \mathrm{HPO}_{4}$ ) using a Varian Cary 50 Bio or a Bio Tek Synergy Mx spectrophotometer and initiated by adding enzyme solution. The assay volume was either 200 or $300 \mu \mathrm{L}$.

Oxidation of ABTS was monitored at $420 \mathrm{~nm}(\varepsilon=$ $\left.36,000 \mathrm{M}^{-1} \mathrm{~cm}^{-1}\right)$, of SGZ at $525 \mathrm{~nm}(\varepsilon=65,000$ $\left.\mathrm{M}^{-1} \mathrm{~cm}^{-1}\right)$ and of $2,6-\mathrm{DMP}$ at $468 \mathrm{~nm}\left(\varepsilon=37,500 \mathrm{M}^{-1}\right.$ $\left.\mathrm{cm}^{-1}\right)$. Laccase activity as a function of $\mathrm{pH}$ was performed in McIlvaine buffer in the $\mathrm{pH}$ range 2-8 for ABTS (0.5 mM), SGZ (0.05 $\mathrm{mM})$ and 2,6-DMP $(0.3 \mathrm{mM})$. The temperature optimum was recorded between $20^{\circ} \mathrm{C}$ and $75^{\circ} \mathrm{C}$ by following ABTS or 2,6-DMP oxidation in an assay volume of $3 \mathrm{~mL}$ using a magnetically stirred, temperature controlled cuvette device. The effect of DMSO on laccase activity was determined by adding $0.4-50 \%(\mathrm{v} / \mathrm{v})$ of solvent to the reaction mixture and following the oxidation of ABTS, SGZ or 2,6-DMP. The stability of laccase was tested by incubating the enzyme in McIlvaine buffer at $\mathrm{pH} 5$ or 7 , potassium phosphate buffer pH 7 and in $\mathrm{ddH}_{2} \mathrm{O}$ at 4, 25, 45 and $65^{\circ} \mathrm{C}$ and subsequently performing an ABTS assay.

Kinetic parameters of purified laccase were determined in McIlvaine buffer at $25^{\circ} \mathrm{C}$ against ABTS 
(10 mM-0.6 $\mu \mathrm{M}, \mathrm{pH} 4$ ), 2,6-DMP (10 mM-0.6 $\mu \mathrm{M}, \mathrm{pH}$ 7) and SGZ (1.25 mM-0.04 $\mu \mathrm{M}$ plus 25\% (v/v) DMSO, $\mathrm{pH}$ 6.5). Enzymatic assays were performed in triplicate. Oxidation of ACS was monitored at $340 \mathrm{~nm}$ by the decrease of substrate absorbance $\left(\varepsilon=1,000 \mathrm{M}^{-1} \mathrm{~cm}^{-1}\right)$ in $0.1 \mathrm{M}$ potassium phosphate buffer $(2.5 \mathrm{mM}-0.04 \mathrm{mM}$, $\mathrm{pH}$ 6.5). The initial rates, recorded within 3 to $10 \mathrm{~min}$, were approximated by non-linear regression algorithms according to the Michaelis-Menten equation using SIGMA-PLOT Enzyme Kinetics software. One unit was defined as the amount of enzyme that oxidized $1 \mu \mathrm{mol}$ of substrate per minute.

\section{Substrate/mediator screening and IC decolorization}

Purified laccase was subjected to a substrate screening. The screening was based on the direct oxidation of the substrate and on the coupled decolorization of IC. Therefore, potential laccase substrates were dissolved in water and $5 \%(\mathrm{v} / \mathrm{v})$ DMSO at a concentration of $10 \mathrm{mM}$ and diluted to a final concentration of $1 \mathrm{mM}$. Reactions were performed in 96-well plates in $0.1 \mathrm{M}$ potassium phosphate buffer, $\mathrm{pH} 6.5$ or 7.8 at $37^{\circ} \mathrm{C}$ with shaking. The reaction was initiated by adding $0.23 \mathrm{U} / \mathrm{mL}$ purified laccase. One unit was defined as the amount of enzyme that oxidized $1 \mu \mathrm{mol}$ of ABTS per minute at room temperature. A UV-Vis scan between 230-700 nm was recorded prior to laccase addition and after 48 hours reaction time.

To evaluate the ability of the purified laccase to decolorize IC, $1 \mathrm{mM}$ of the dye was dissolved in water and incubated with $0.1 \mathrm{mM}$ of the potential mediator substrate. The reaction was initiated by the addition of laccase which was substituted with water in the control reaction. The reaction was followed over a period of $48 \mathrm{~h}$ at intervals of $30 \mathrm{~min}$ and was performed at $37^{\circ} \mathrm{C}$. The change in absorbance (for $\lambda=350,420,550,570,610$ and $650 \mathrm{~nm}$ ) was recorded to follow IC decolorization. Although IC showed a maximum absorbance at $610 \mathrm{~nm}$, decolorization was calculated based on the shoulder at $650 \mathrm{~nm}$. In this way it was possible to follow starting concentrations of $1 \mathrm{mM}$ as the Lambert-Beer law was still valid under these conditions. Furthermore, no by-product was detected at $650 \mathrm{~nm}$ as opposed to $610 \mathrm{~nm}$. The decolorization was further assessed by varying the IC to ACS ratio in the presence and absence of laccase.

Decolorization (\%) was calculated based on the difference in absorbance at $650 \mathrm{~nm}$ in reactions with and without laccase and defined as:

$$
\text { Decolorization }(\%)=100-\frac{\text { absorbance }_{t 48-\text { lacase }} \times 100}{\text { absorbance }_{t 48 \_c o n t r o l}}
$$

Decolorization reactions were carried out in the presence and in the absence of laccase. The absorbance measured after $48 \mathrm{~h}$ in reactions lacking laccase was then defined as $100 \%$ (absorbance $\mathrm{t}_{\mathrm{t} 8 \mathrm{~B} \text { control}}$ ).

\section{Results}

\section{Cloning of $\cot A$ from Bacillus pumilus}

A Protein Blast search for uncharacterized bacterial laccases was performed using the CotA amino acid sequence of Bacillus subtilis as template. Out of numerous homologues, a hypothetical protein annotated as "spore coat protein A" found in the fully sequenced genome of Bacillus pumilus ATCC 7061 was selected for cloning and recombinant expression in $E$. coli due to its relatively close relation to other already characterized Bacillus laccases. The B. pumilus DSM 27 sequence encoding a CotA-like protein was cloned into the expression vector $\mathrm{pQE}-60$ as described in Methods. The cloned sequence exhibited $99.8 \%$ amino acid identity to the CotA sequence of B. pumilus ATCC7061, with K79E being the only difference. CotA of B. pumilus DSM 27 exhibited 68\% amino acid identity and 79\% similarity to CotA of $B$. subtilis, which is the best studied bacterial laccase [22,28]. Amino acid identity and similarity to the second previously characterized CotA laccase from B. licheniformis ATCC 7061 (accession no. YP_077905, [25]) was $62 \%$ and $76 \%$, respectively. CotA of $B$. pumilus consists of 510 amino acids (hypothetical molecular weight: $58.6 \mathrm{kDa}$ ), which is close to the length of 513 amino acids for both the B. subtilis and B. licheniformis laccases. The ligands which bind T1 copper (M502, H419, C492, H497), T2 copper (H105, H422) and T3 copper (H107, H153, H155, H424, H491, $\mathrm{H} 493)$ in B. subtilis CotA [22] were all conserved in B. pumilus CotA. The cysteine residues C229 and C322 which have been proposed to form a disulfide bond in B. subtilis CotA [29] were also conserved in B. pumilus CotA.

\section{Recombinant expression and purification CotA laccase} For production of B. pumilus laccase with E. coli JM109 (pBpL6) special growth and induction procedures were applied which had been described previously [26]. Similarly to B. subtilis CotA, the use of reduced cultivation temperature before and after induction, the addition of high concentrations of $\mathrm{Cu}^{2+}$ at induction and static incubation in the second phase of CotA expression as stated in materials and methods yielded maximal amounts of fully copper-loaded, active $B$. pumilus enzyme.

The supernatant from cells expressing laccase was incubated at $70^{\circ} \mathrm{C}$ for $20 \mathrm{~min}$, as described for other Bacillus laccases expressed in E. coli $[25,30]$. This treatment results in denaturation of most $E$. coli proteins and is used to enrich heat resistant proteins such as spore-coat associated laccases. Above $90 \%$ of the initial laccase activity was recovered in the supernatant after 
centrifugation of heat-treated lysate. Subsequent column purifications included anion exchange and size exclusion chromatography, yielding a single protein band of approximately $30 \mathrm{kDa}$, as shown by SDS-PAGE analysis in Figure 1. The apparent molecular weight of the expressed laccase was much lower than the expected one of approximately $58 \mathrm{kDa}$, when proteins were separated by SDS-PAGE under standard conditions (5 min, $95^{\circ} \mathrm{C}$, in buffer containing $6 \%$ SDS and $10 \% \beta-$ mercapthoethanol). However, when the protein was boiled for $20 \mathrm{~min}$, the band migrated at the expected molecular weight, suggesting that full denaturation of the protein required extra heat.

\section{Biochemical properties of $B$. pumilus laccase CotA}

Purified protein samples showed a strong blue color, and copper content determination revealed a molar copper to protein ratio of 3.9 , affirming a fully copperloaded enzyme. The $\mathrm{pH}$ optima of CotA activity were determined to be around $\mathrm{pH} 4$ for ABTS, $\mathrm{pH} 7$ for 2,6DMP and pH 6.5 for SGZ. These values were very similar to those found for other Bacillus CotA laccases $[25,28]$. The temperature optimum for ABTS oxidation

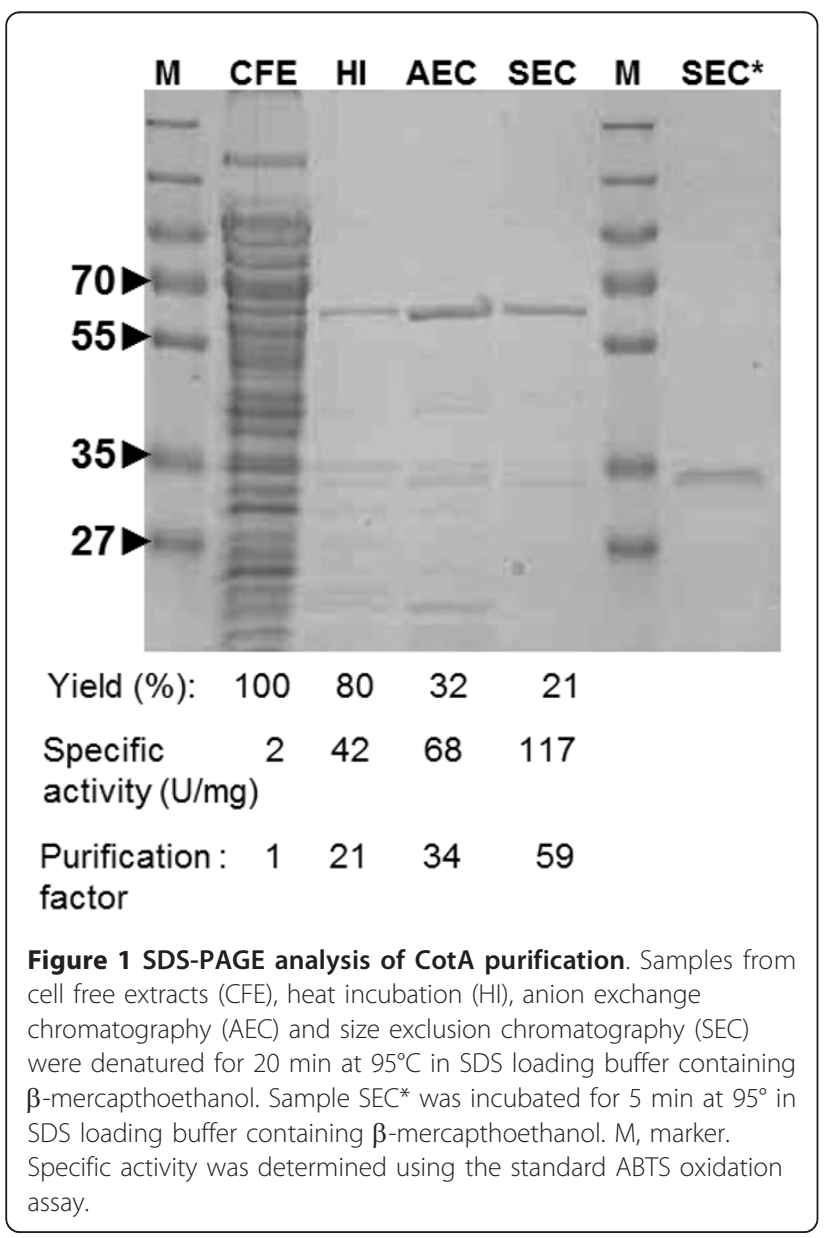

was determined to be between $55-75^{\circ} \mathrm{C}$. For 2,6 -DMP oxidation a steady increase of activity up to $70^{\circ} \mathrm{C}$ was monitored, again demonstrating the high temperature tolerance of CotA laccase. For detailed temperatureactivity and $\mathrm{pH}$-activity profiles see Additional file 2 .

Kinetic parameters of recombinant $B$. pumilus laccase for ABTS, 2,6-DMP and SGZ oxidation were determined and are shown in Table 1. Michaelis-Menten plots for all substrates are given in Additional file 3 . The values obtained for ABTS and 2,6-DMP were more similar to those obtained for B. subtilis than for B. licheniformis laccase $[25,26]$. It was not possible to determine the kinetic parameters for SGZ due to its low solubility. The observed kinetics did not fit a Michaelis-Menten equation. Instead, only a linear correlation was observed. This was true either when low SGZ (6-78 $\mu \mathrm{M})$ and DMSO concentrations $(<0.8 \% \mathrm{v} / \mathrm{v})$ or high SGZ $(0.08$ $1.25 \mathrm{mM})$ and DMSO $(25 \% \mathrm{v} / \mathrm{v}$, leading to maximal rates of SGZ oxidation, see Fig. 2) concentrations were used. Hence, no $K_{\mathrm{M}}$ can be given for SGZ oxidation. Nevertheless, a rough estimate of $k_{\text {cat }}$ was deduced from the highest observed reaction rates measured with either $<0.8 \%(\mathrm{v} / \mathrm{v})$ or $25 \%(\mathrm{v} / \mathrm{v})$ DMSO (data marked with * in Table 1).

SGZ required the presence of DMSO to enable its solubility. The effect of increasing concentrations of DMSO upon laccase activity was therefore investigated. To this end, ABTS, 2,6-DMP and SGZ oxidations were measured in the presence of increasing DMSO concentrations (Figure 2). It was found that SGZ oxidation rates were enhanced with increasing concentrations of DMSO with an optimum at around $25 \%(\mathrm{v} / \mathrm{v})$. Concentrations above $50 \%$ (up to $90 \%$ ) did not result in further enhanced activity, but rather deactivated the enzyme rapidly (data not shown). For ABTS and 2,6-DMP any addition of DMSO led to a gradually decreased oxidation rate; however, the effect was much more severe for ABTS.

The kinetic stability upon storage of the enzyme was also investigated. Protein samples were incubated in McIlvaine buffer at $\mathrm{pH} 5$ and 7 , potassium phosphate buffer at $\mathrm{pH} 7$ and $\mathrm{dd}_{2} \mathrm{O}$ at $4,25,45$ and $65^{\circ} \mathrm{C}$. ABTS oxidation was measured periodically. The half-life of laccase is summarized in Table 2. Within 1 hour, all laccase preparations in Mcllvaine buffer $\mathrm{pH} 5$ showed over $75 \%$ loss of activity. Enzyme samples stored in either McIlvaine or phosphate buffer at $\mathrm{pH} 7$ showed over $50 \%$ loss in activity after $1 \mathrm{~h}$. Unexpectedly, this significant loss was not detected for the samples stored in deionized water.

\section{Substrate range of $B$. pumilus laccase $\operatorname{Cot} A$}

The catalytic activity of purified CotA was screened against a panel of 37 structurally different potential substrates of both synthetic and natural origin. 
Table 1 Kinetic constants of purified laccase from Bacillus species for ABTS, 2,6-DMP and SGZ oxidation

\begin{tabular}{|c|c|c|c|c|c|c|c|c|c|}
\hline \multicolumn{10}{|l|}{ Substrate } \\
\hline \multirow[t]{2}{*}{ Laccases } & \multicolumn{3}{|c|}{ ABTS } & \multicolumn{3}{|c|}{ 2, 6-DMP } & \multicolumn{3}{|r|}{ SGZ } \\
\hline & $\overline{K_{M}(\mu \mathrm{M})}$ & $k_{\text {cat }}\left(\mathrm{s}^{-1}\right)$ & $\begin{array}{c}\text { Assay } \\
\text { conditions }\end{array}$ & $K_{\mathrm{M}}(\mu \mathrm{M})$ & $k_{\text {cat }}\left(\mathrm{s}^{-1}\right)$ & $\begin{array}{c}\text { Assay } \\
\text { conditions }\end{array}$ & $K_{\mathrm{M}}(\mu \mathrm{M})$ & $k_{\text {cat }}\left(\mathrm{s}^{-1}\right)$ & Assay conditions \\
\hline \multirow[t]{2}{*}{ B. pumilus } & $80 \pm 4$ & $291 \pm 2.7$ & $\begin{array}{c}0.6 \mu \mathrm{M}-10 \mathrm{mM}, \\
\mathrm{pH} 4, \mathrm{RT}\end{array}$ & $680 \pm 27$ & $11 \pm 0.1$ & $\begin{array}{c}0.6 \mu \mathrm{M}-10 \mathrm{mM} \\
\mathrm{pH} \text { 7, RT }\end{array}$ & n.d. & *4.9 & $\begin{array}{c}6-78 \mu \mathrm{M},<0.8 \%(\mathrm{v} / \mathrm{v}) \mathrm{DMSO} \\
\mathrm{pH} 6.5, \mathrm{RT}\end{array}$ \\
\hline & & & & & & & n.d. & ${ }^{*} 66 \pm 1.5$ & $\begin{array}{c}0.04 \mu \mathrm{M}-1.25 \mathrm{mM}(25 \%(\mathrm{v} / \mathrm{v}) \\
\text { DMSO), pH 7, RT }\end{array}$ \\
\hline B. subtilis [26] & $124 \pm 17$ & $322 \pm 20$ & $\begin{array}{c}10-200 \mu \mathrm{M} \mathrm{pH} \\
4,37^{\circ} \mathrm{C}\end{array}$ & $216 \pm 35$ & $29 \pm 4$ & $\begin{array}{c}10-200 \mu \mathrm{M}, \mathrm{pH} \\
7,37^{\circ} \mathrm{C}\end{array}$ & $18 \pm 3$ & $80 \pm 4$ & $1-100 \mu \mathrm{M}, \mathrm{pH} 7,37^{\circ} \mathrm{C}$ \\
\hline $\begin{array}{l}\text { B. licheniformis } \\
\text { [25] }\end{array}$ & $6.5 \pm 0.2$ & 83 & $\begin{array}{c}5-500 \mu \mathrm{M} p \mathrm{pH} \\
4, \mathrm{RT}\end{array}$ & $56.7 \pm 1$ & 28 & $\begin{array}{c}5-1000 \mu \mathrm{M}, \mathrm{pH} \\
\text { 7, RT }\end{array}$ & $4.3 \pm 0.2$ & 100 & $1.25-50 \mu \mathrm{M}, \mathrm{pH} 7, \mathrm{RT}$ \\
\hline
\end{tabular}

Substrate ranges covered, $\mathrm{pH}$ and temperature are listed. n.m.: not measurable, due to substrate solubility. ${ }^{*}$ The value was deduced from the highest observed rate.

The activity was measured at a substrate concentration of $1 \mathrm{mM}$. A UV-Vis scanning between 230-700 nm was recorded prior to laccase addition and after $48 \mathrm{~h}$ reaction time. By this method only substrates leading to a changed UV spectrum upon oxidation were detectable. From the 37 compounds tested, a change of absorbance was detected for 18 compounds (Table 3). Control reactions lacking laccase were performed in parallel, to exclude the possibility of non-enzymatic oxidation.

In addition, all substrates were tested for their ability to function as mediator in the decolorization of the dye IC (Table 3). The relative decrease of absorbance was determined spectrophotometrically as a measure of the degree of mediated oxidation of IC. For the mediator screen, $1 \mathrm{mM}$ IC was combined with $0.1 \mathrm{mM}$ of the substrate. The results are summarized in Table 3 .

Amongst the 37 compounds tested, 18 showed a change of absorbance as a result of laccase promoted

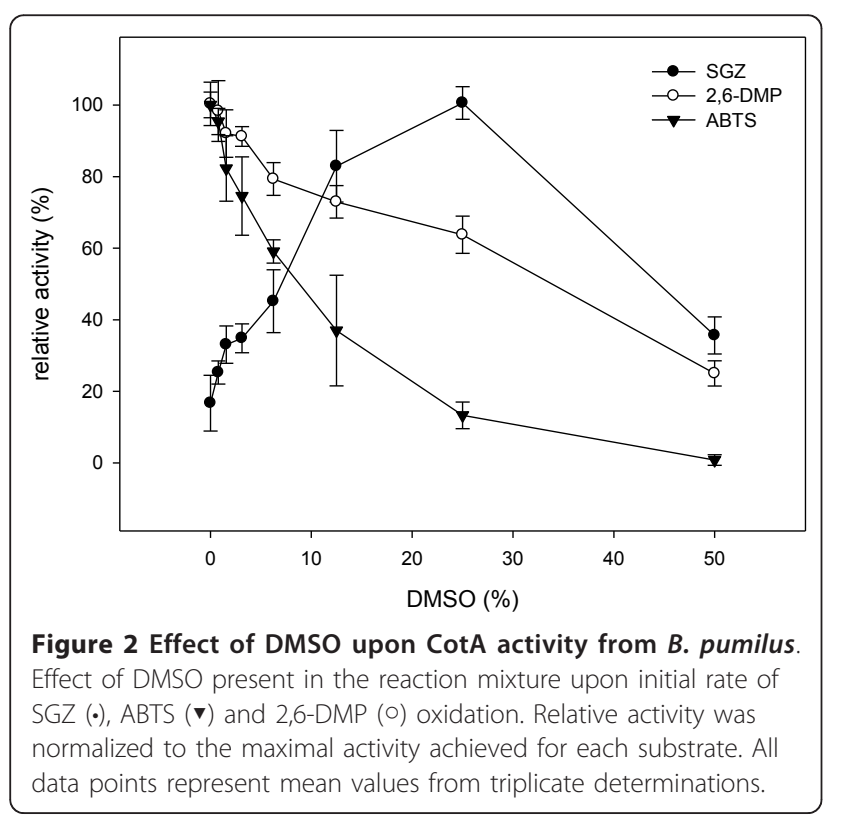

oxidation. In turn, three of these compounds, ABTS (37), ACS (18) and syringaldehyde (20) functioned as mediators and completely decolorized IC within 3 hours. Within 48 hours, two compounds promoted decolorization of $25 \%$ (5) and $40 \%$ (14), respectively. Laccase alone lead to a decolorization of $20 \%$ within 48 hours at $\mathrm{pH}$ 6.8. All other compounds did not lead to a decolorization of more than $20 \%$ and therefore cannot be considered as mediators for IC oxidation.

ACS was selected for further studies and its potential as a mediator for the decolorization of IC was evaluated. In the screening, experiments were conducted with $0.1 \mathrm{mM}$ ACS and $1 \mathrm{mM}$ IC (1:10 ratio). This ratio was decreased to 1:100 (Figure 3A and 3B) and 1:1000 (Figure $3 \mathrm{C}$ and $3 \mathrm{D}$ ) with IC starting concentrations of $0.25 \mathrm{mM}$ and $1 \mathrm{mM}$, respectively. Furthermore, the $\mathrm{pH}$ effect was evaluated by performing the reactions at $\mathrm{pH}$ 6.5 and 7.8. Direct decolorization of IC by laccase was monitored in reactions lacking ACS.

Both mediated and non-mediated reactions were more efficient at higher $\mathrm{pH}$. Although IC was partially (at $\mathrm{pH}$ 6.5) and completely (at $\mathrm{pH} 7.8$ ) decolorized by laccase alone within $48 \mathrm{~h}$, the mediated reactions proceeded faster, most notably at IC:ACS ratio of 1:100. It was found that mediated reactions at IC:ACS ratio of 1:100 completely decolorized IC at both $\mathrm{pH}$ values. However, at IC:ACS ratio of 1:1000, only reactions at $\mathrm{pH} 7.8$ were completed. Independently of the $\mathrm{pH}$, the rates of ACS mediated reactions performed at an IC:ACS ratio of 1:1000 and non-mediated reactions were almost the same. This indicated that ACS concentrations

Table 2 Half-life of laccase measured by ABTS oxidation

\begin{tabular}{lcccc}
\hline & $\mathbf{4}^{\circ} \mathbf{C}$ & $\mathbf{2 5}^{\circ} \mathbf{C}$ & $\mathbf{4 5}^{\circ} \mathbf{C}$ & $\mathbf{6 5}^{\circ} \mathbf{C}$ \\
\hline Mclllvaine buffer pH 7 & 1.0 & 0.75 & 0.32 & 0.28 \\
\hline Potassium phosphate buffer $\mathrm{pH} \mathrm{7}$ & 0.93 & 0.79 & 0.45 & 0.34 \\
\hline Deionized water & 144 & 40.0 & 19.3 & 3.5 \\
\hline
\end{tabular}

The purified protein was stored in different solvents and at various temperatures. Half-lives are given in hours. 
Table 3 Substrate screen for laccase activity and IC decolorization Change of absorbance $(\Delta A):+($ change of absorbance), - (no change of absorbance)

\begin{tabular}{|c|c|c|c|c|}
\hline Structure & Compound & $\mathrm{n}^{\circ}$ & $\Delta A$ & IC \\
\hline & $\mathrm{R} 1=\mathrm{R} 2=\mathrm{H}$ & 1 & - & 0 \\
\hline & $\mathrm{R} 1=\mathrm{H}, \mathrm{R} 2=\mathrm{OH}$ & 2 & - & 0 \\
\hline & $\mathrm{R} 1=\mathrm{OH}, \mathrm{R} 2=\mathrm{H}$ & 3 & - & 0 \\
\hline & $\mathrm{R} 1=\mathrm{R} 2=\mathrm{OH}$ & 4 & + & 0 \\
\hline & $\mathrm{R} 1=\mathrm{OH}, \mathrm{R} 2=\mathrm{OCH}_{3}$ & 5 & + & 25 \\
\hline & $\mathrm{R} 1=\mathrm{OH}, \mathrm{R} 2=\mathrm{R} 3=\mathrm{H}$ & 6 & - & 0 \\
\hline & $\mathrm{R} 1=\mathrm{R} 2=\mathrm{OH}, \mathrm{R} 3=\mathrm{H}$ & 7 & + & 0 \\
\hline & $\mathrm{R} 1=\mathrm{R} 2=\mathrm{R} 3=\mathrm{OH}$ & 8 & + & 0 \\
\hline & $\mathrm{R} 1=\mathrm{OH}, \mathrm{R} 2=\mathrm{R} 3=\mathrm{OCH}_{3}$ & 9 & + & 0 \\
\hline & $\underline{\mathrm{R}} 1=\mathrm{OH}, \mathrm{R} 2=\mathrm{NH}_{2}, \mathrm{R} 3=\mathrm{H}$ & 10 & + & 0 \\
\hline & $\mathrm{R} 1=\mathrm{NH}_{2}, \mathrm{R} 2=\mathrm{OH}, \mathrm{R} 3=\mathrm{H}$ & 11 & + & 0 \\
\hline & $\mathrm{R} 1=\mathrm{OH}, \mathrm{R} 2=\mathrm{F}, \mathrm{R} 3=\mathrm{H}$ & 12 & - & 0 \\
\hline & $\mathrm{R} 1=\mathrm{OH}, \mathrm{R} 2=\mathrm{H}$ & 13 & - & 0 \\
\hline & $\mathrm{R} 1=\mathrm{OH}, \mathrm{R} 2=\mathrm{OCH}_{3}$ & 14 & + & 40 \\
\hline & $\mathrm{R} 1=\mathrm{OCH}_{3}, \mathrm{R} 2=\mathrm{OH}$ & 15 & + & 0 \\
\hline & & 16 & - & 0 \\
\hline & $\mathrm{R}=\mathrm{H}$ & 17 & - & 0 \\
\hline & $\mathrm{R}=\mathrm{OCH}_{3}$ & 18 & + & $>99$ \\
\hline & $\mathrm{R} 1=\mathrm{OH}, \mathrm{R} 2=\mathrm{R} 3=\mathrm{H}$ & 19 & - & 0 \\
\hline & $\mathrm{R} 1=\mathrm{H}, \mathrm{R} 2=\mathrm{OH}, \mathrm{R} 3=\mathrm{OCH}_{3}$ & 20 & + & $>99$ \\
\hline & & 21 & + & 0 \\
\hline & & 22 & - & 0 \\
\hline & $\mathrm{R}=\mathrm{H}$ & 23 & - & 0 \\
\hline & $\mathrm{R}=\mathrm{OH}$ & 24 & + & 0 \\
\hline
\end{tabular}


Table 3 Substrate screen for laccase activity and IC decolorization Change of absorbance $(\Delta ? \Delta ? A):+$ (change of absorbance), - (no change of absorbance) (Continued)

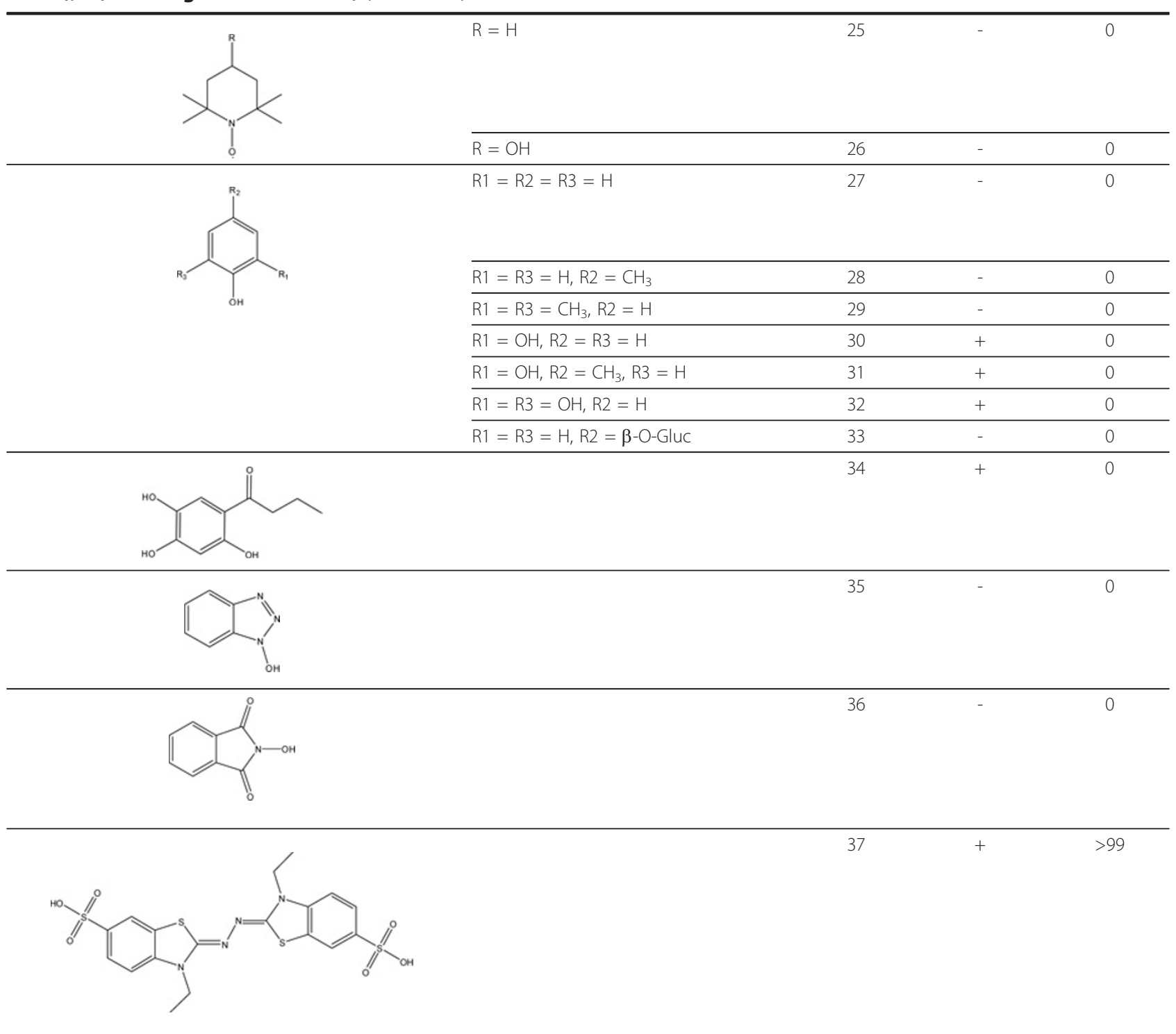

Indigocarmine decolorization (\%) (IC) is given compared to the control reaction lacking laccase.

significantly below the $K_{\mathrm{m}}$, which was determined to be $30 \mathrm{mM}$, had no influence on the reaction kinetics.

Decolorization reactions were also conducted with $10 \mathrm{mM}$ IC and 1:100 and 1:1000 ratios of IC:ACS at $\mathrm{pH}$ 6.5 and 7.8. As a control, direct oxidation was monitored in reactions lacking ACS. Although the initial absorbance could not be detected spectrophotometrically $\left(\mathrm{OD}_{650 \mathrm{~nm}}>4\right)$, complete decolorization within 72 hours was observed for the reaction performed at an IC: ACS ratio of 1:100 and $\mathrm{pH}$ 7.8. No measurable bleaching was observed for the non-mediated reaction or any of the other control reactions conducted. In reactions which lead to complete decolorization of IC at $\lambda=$ $650 \mathrm{~nm}$, a red soluble reaction product with an absorbance maximum at $\lambda=550 \mathrm{~nm}$ was formed. The formation of a red product during laccase-catalyzed IC transformation has previously been reported and presumably is due to the condensation of two IC molecules [31,32].

\section{Discussion}

Laccases are versatile biocatalysts for industrial applications. Much research has been done with fungal laccases; however, recently more information has become available also for bacterial laccases [33]. We have identified a novel CotA-type laccase by homology searches in public protein databases. The laccase from Bacillus pumilus DSM 27 was cloned, purified and biochemically characterized. The purified fully copper loaded protein was found to be a 

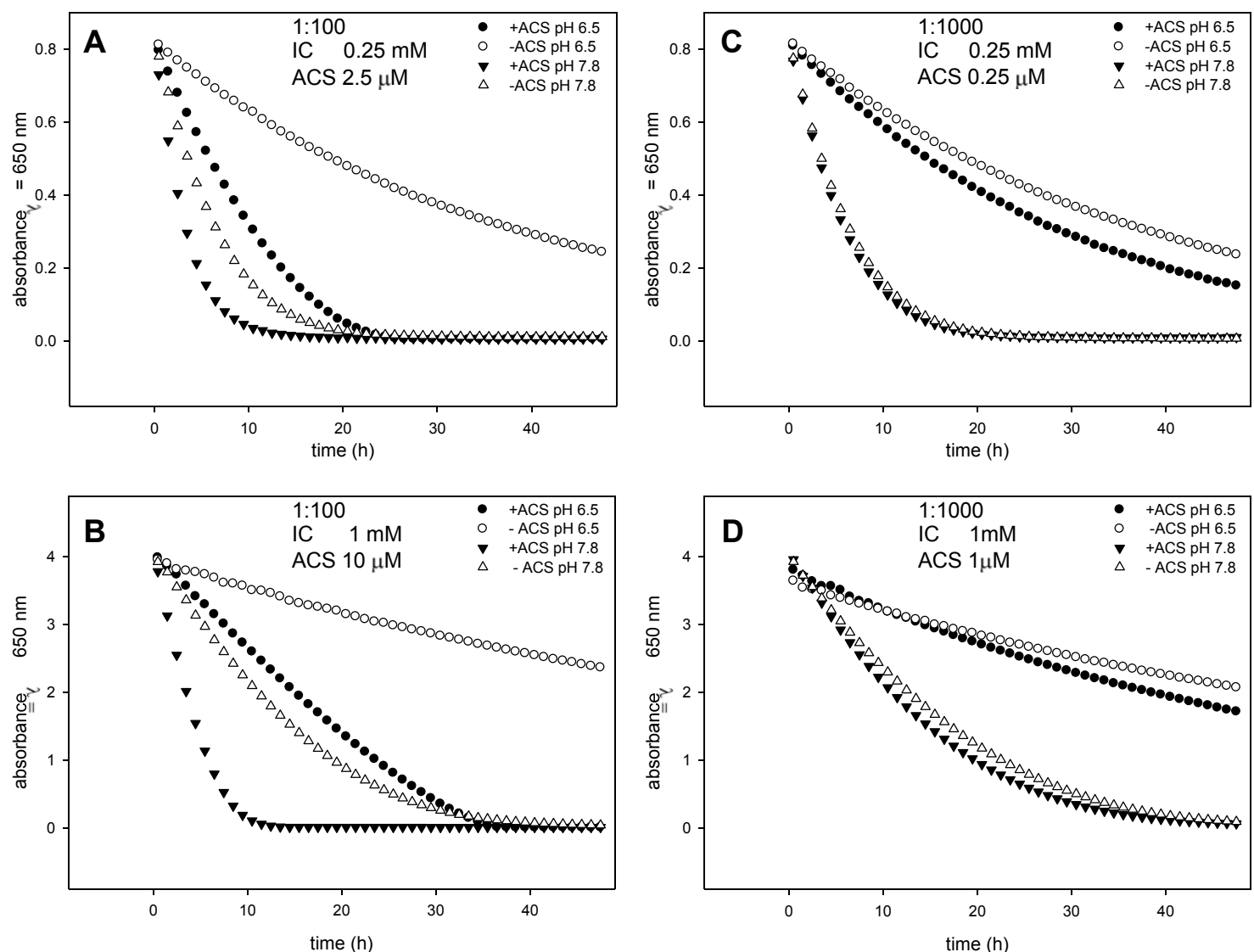

Figure 3 IC transformation. Time course of IC degradation by purified laccase from B. pumilus monitored spectroscopically at $\lambda=650 \mathrm{~nm}$ over a total of $48 \mathrm{~h}$ at $37^{\circ} \mathrm{C}$. Reactions were conducted at pH 6.5 and 7.8, in the presence or absence of ACS. (A) $0.25 \mathrm{mM} \mathrm{IC}$ and ACS added at a ratio of 1:100. (B) $1 \mathrm{mM} \mathrm{IC}$ and ACS added at a ratio 1:100. (C) $0.25 \mathrm{mM} \mathrm{IC}$ and ACS added at a ratio of 1:1000. (D) $1 \mathrm{mM}$ IC and ACS added at a ratio of 1:1000

monomeric $58 \mathrm{kDa}$ recombinant protein, which exhibited a blue color, due to the characteristic absorbance of the chelated T1 copper site at $600 \mathrm{~nm}$ [2].

Laccase from $B$. pumilus constitutes a highly thermostable protein. The $\mathrm{pH}$ optimum for ABTS, 2,6-DMP and SGZ, as well as the temperature optimum between $55-75^{\circ} \mathrm{C}$ were similar to $B$. subtilis and $B$. licheniformis laccases $[25,26]$. Thermal stability studies showed that our laccase maintained activity best when stored in water. Therefore, selection of the appropriate storage solvent seems to be crucial for Bacillus laccases in order to maintain high levels of active protein for either storage or in biotransformation reactions.

Kinetic constants for ABTS and 2,6-DMP were within the range of data reported for $B$. subtilis and compared favorably to that of fungal laccases $[34,35]$. However, the $K_{\mathrm{M}}$ for SGZ was not measurable and a $k_{\text {cat }}$ value of $66 \mathrm{~s}^{-1}$ could only be estimated from the highest observed reaction rate at $1.25 \mathrm{mM} \mathrm{SGZ}$ and $25 \%(\mathrm{v} / \mathrm{v})$ DMSO. The initial rate of SGZ oxidation was highest when the reaction mixture was supplemented with $25 \%$ (v/v) DMSO. By contrast, any addition of DMSO to reactions performed with ABTS and 2,6-DMP lead to an immediate decline of activity, probably due partial denaturation or inhibition of the enzyme. In the case of SGZ, the increased solubility of the substrate at increasing DMSO concentrations presumably over-compensates negative effects of the co-solvent. An inhibitory effect of DMSO on laccase catalyzed oxidation of 2,6DMP has been previously reported for an enzyme from Pyricularia oryzae [36]. Increasing amounts of DMSO were also added to laccase from Trametes sp. and the conversion of 4-hydroxybiphenyl decreased with increasing DMSO concentrations. However, the study was only carried out for DMSO concentrations between 30 to $70 \%$, as the substrate was not soluble below 30\% [37]. We conclude from our data that DMSO up to $25 \%(\mathrm{v} / \mathrm{v})$ can be used as a co-solvent for enhancing the solubility of hydrophobic substrates in biotransformations with CotA-type laccases.

To explore the potential of laccase as a biocatalyst a substrate screen for 37 non-comprehensive compounds was 
performed. Both, different substituted phenols and nonphenolic substrates were tested qualitatively. It was found that purified laccase from $B$. pumilus exhibited a broad substrate spectrum. Oxidizing activity towards 18 compounds was detected, which was in many cases accompanied by the associated color formation. No activity was detected for the non-phenolic substrates 1, 22, 25, 26, 35 and 36, which might be due to the lack of a changed spectroscopic signal upon oxidation. However, it was observed that phenolic substrates were preferably oxidized when at least one $-\mathrm{OH}$ or $-\mathrm{OCH}_{3}$ with a lone pair of electrons was adjacent to the phenol, such as substrates $4,5,7, \mathbf{8}, \mathbf{9}, \mathbf{1 0}$, $11,14,15,18,20,21,24,30,31,32$, and 34. For substrates 16, 17 and 19, no activity could be detected, although one ortho position was substituted with an $-\mathrm{OCH}_{3}$. For these compounds to function as substrates, a substitution at both ortho positions might be vital. Kinetic studies with a number of basidomycetes suggested that the higher activity for sinapic acid compared to ferulic acid could be the result of the additional $-\mathrm{OCH}_{3}$ group [38]. A similar correlation between activity and substitution pattern has been described for laccase from Trametes trogii, Streptomyces ipomoea, Pleurotus ostreatus and B. licheniformis [25,39-41]. The fact that the ortho $-\mathrm{H}$ or $-\mathrm{CH}_{3}$ substituted substrates $2,3,6,13,23,27,28,29$ and 33 were not oxidized is in line with the proposed requirement for the aforementioned substitution pattern. The oxidizing activity of laccase might be rationalized based on the principle of inductive and mesomeric effects. The substrate screen revealed that the enzyme preferably oxidizes substituted phenols with at least one ortho - or para - substituent bearing a lone pair of electrons, contributing to the positive mesomeric effect. As a consequence, the electron density at the phenoxy- $\mathrm{OH}$ is increased, thus facilitating an electron abstraction that yields a phenoxy radical. Compound 12 is not oxidized because the negative inductive effect of halogens such as fluorine is dominating over the positive mesomeric effect.

The substrates were also tested for their potential to act as mediator in the IC decolorization. For three compounds, namely ABTS (31), syringaldehyde (14) and ACS (12), a complete decolorization was achieved using LMS with $B$. pumilus laccase. A number of groups have reported on the direct or mediated IC decolorization using bacterial as well as fungal laccase $[7,14,15,17,19,42]$. Routinely, reactions were carried out using $20-100 \mu \mathrm{M}$ IC in combination with various mediators that were added in equimolar amounts or in a molar ratio of 1:10. Successfully employed mediators, which led to best decolorization results, were syringaldehyde, acetosyringone and violuric acid. A true mediator should be added in catalytic amounts. Yet, in most studies on dye decolorization the mediators are added in high stoichiometric amounts. In our study, we reduced the mediator to dye ratio to 1:100 and found that ACS functioned as a "true" mediator, which significantly enhanced the decolorization rate. Only three of the 18 substrates tested functioned as mediators for the decolorization of IC. The other identified primary substrates might still function as mediators for the oxidation of other dyes/secondary substrates.

\section{Conclusions}

In summary, laccase from B. pumilus was cloned, expressed and biochemically characterized. It was shown to constitute a versatile biocatalyst and was successfully applied in the decolorization of up to $10 \mathrm{mM} \mathrm{IC}$ in the presence of catalytic amounts of mediators. We concluded that CotA from B. pumilus has great potential as biocatalyst due to its thermo stability, $\mathrm{pH}$ optimum in the neutral to alkaline range and broad substrate spectrum.

\section{Additional material}

\begin{abstract}
Additional file 1: Map of the constructed plasmid pBpL6 used for expression of CotA laccase from B. pumilus

Additional file 2: $\mathrm{pH}$ dependence and temperature optimum of CotA activity from $B$. pumilus. (A) Oxidation of ABTS ( $0.5 \mathrm{mM}), 2,6-$ $\operatorname{DMP}(\cdot 0.3 \mathrm{mM})$ and SGZ $(\wedge 0.05 \mathrm{mM})$ by the purified laccase as a function of $\mathrm{pH}$ at $25^{\circ} \mathrm{C}$. Relative activities were normalized to the maximal activity achieved for each substrate at the optimum $\mathrm{pH}$, which was taken as 100\% (corresponds to 200, 4.3 and $5.4 \mathrm{U} / \mathrm{mg}$ for ABTS, 2,6 DMP and SGZ respectively). The oxidation by laccase as a function of temperature is given relative to the highest activity recorded, which was taken as $100 \%$. This corresponds to $24.8 \mathrm{U} / \mathrm{mg}$ for (B) 2,6-DMP $(0.3 \mathrm{mM}$, $\mathrm{pH} 7)$ and $857 \mathrm{U} / \mathrm{mg}$ for $(\mathrm{C}) \mathrm{ABTS}(0.5 \mathrm{mM}, \mathrm{pH} 4)$. All data points represent mean values from triplicate determinations.

Additional file 3: Michaelis-Menten plots obtained with purified CotA laccase from $B$. pumilus. The specific activity $(U / \mathrm{mg})$ was plotted versus the substrate concentration for (A) ABTS, (B) 2,6-DMP and (C) SGZ $(25 \%(\mathrm{~V} / \mathrm{V}) \mathrm{DMSO})$. All data points represent mean values \pm standard error from triplicate determinations.
\end{abstract}

List of abbreviations

2,2': Azino-bis(3-ethylbenzthiazoline-6-sulphonic acid) (ABTS);

2,6: Dimethoxyphenol (2,6-DMP);

(SGZ): Syringaldazine;

(LMS): Laccase mediator systems;

(IC): Indigocarmine;

\section{Acknowledgements}

We thank Luzia Wiesli, Kathrin Grieder and Sultan Kiybar for technical assistance and Michael Richter and Michael Fairhead for critically reading the manuscript.

\section{Authors' contributions}

RR participated in the design of the study, carried out the experiment and in writing the manuscript. Jl participated in the design of the study, carried out the cloning and helped to draft the manuscript. LMT conceived the study, provided financial and administrative support and participated in the design of the study and writing the manuscript. All authors read and approved the final manuscript.

\section{Competing interests}

The authors declare that they have no competing interests.

Received: 23 June 2010 Accepted: 25 January 2011

Published: 25 January 2011 


\section{References}

1. Hoegger PJ, Kilaru S, James TY, Thacker JR, Kues U: Phylogenetic comparison and classification of laccase and related multicopper oxidase protein sequences. FEBS J 2006, 273(10):2308-2326.

2. Solomon El, Augustine $\mathrm{AJ}$, Yoon $\mathrm{J}: \mathrm{O}_{2}$ reduction to $\mathrm{H}_{2} \mathrm{O}$ by the multicopper oxidases. Dalton Transactions 2008, , 30: 3921-3932.

3. Witayakran S, Ragauskas AJ: Synthetic applications of laccase in green chemistry. Adv Synth Catal 2009, 351(9):1187-1209.

4. Sharma P, Goel R, Capalash N: Bacterial laccases. World J Microbiol Biotechnol 2007, 23(6):823-832.

5. Kunamneni A, Camarero S, Garcia-Burgos C, Plou FJ, Ballesteros A, Alcalde M: Engineering and applications of fungal laccases for organic synthesis. Microb Cell Fact 2008, 7.

6. Baldrian P, Merhautova V, Gabriel J, Nerud F, Stopka P, Hruby M, Benes MJ: Decolorization of synthetic dyes by hydrogen peroxide with heterogeneous catalysis by mixed iron oxides. Applied Catalysis BEnvironmental 2006, 66(3-4):258-264.

7. Hu MR, Chao YP, Zhang GQ, Xue ZQ, Qian SJ: Laccase-mediator system in the decolorization of different types of recalcitrant dyes. J Ind Microbiol Biotechnol 2009, 36(1):45-51.

8. Couto SR, Herrera JLT: Industrial and biotechnological applications of laccases: A review. Biotechnol Adv 2006, 24(5):500-513.

9. Vanhulle S, Trovaslet M, Enaud E, Lucas M, Taghavi S, Van Der Lelie D, Van Aken B, Foret M, Onderwater RCA, Wesenberg D, et al: Decolorization, cytotoxicity, and genotoxicity reduction during a combined ozonation/ fungal treatment of dye-contaminated wastewater. Environ Sci Technol 2008, 42(2):584-589.

10. Khlifi R, Belbahri L, Woodward S, Ellouz M, Dhouib A, Sayadi S, Mechichi T: Decolourization and detoxification of textile industry wastewater by the laccase-mediator system. J Hazard Mater 2010, 175:802-808.

11. Johannes C, Majcherczyk A: Natural mediators in the oxidation of polycyclic aromatic hydrocarbons by laccase mediator systems. Appl Environ Microbiol 2000, 66(2):524-528.

12. Gonzalez MD, Vidal T, Tzanov T: Electrochemical study of phenolic compounds as enhancers in laccase-catalyzed oxidative reactions. Electroanalysis 2009, 21(20):2249-2257.

13. Abadulla E, Tzanov T, Costa S, Robra KH, Cavaco-Paulo A, Gubitz GM: Decolorization and detoxification of textile dyes with a laccase from Trametes hirsuta. Appl Environ Microbiol 2000, 66(8):3357-3362.

14. Camarero S, Ibarra D, Martinez MJ, Martinez AT: Lignin-derived compounds as efficient laccase mediators for decolorization of different types of recalcitrant dyes. Appl Environ Microbiol 2005, 71(4):1775-1784.

15. Colao MC, Lupino S, Garzillo AM, Buonocore V, Ruzzi M: Heterologous expression of $\mathrm{Icl}$ gene from Trametes trogii in Pichia pastoris and characterization of the recombinant enzyme. Microb Cell Fact 2006, 5:31.

16. Kunamneni A, Ghazi I, Camarero S, Ballesteros A, Plou FJ, Alcalde M: Decolorization of synthetic dyes by laccase immobilized on epoxyactivated carriers. Process Biochem 2008, 43(2):169-178.

17. Dube E, Shareck F, Hurtubise Y, Daneault C, Beauregard M: Homologous cloning, expression, and characterisation of a laccase from Streptomyces coelicolor and enzymatic decolourisation of an indigo dye. Appl Microbiol Biotechnol 2008, 79(4):597-603.

18. Pereira L, Coelho AV, Viegas CA, dos Santos MMC, Robalo MP, Martins LO: Enzymatic biotransformation of the azo dye Sudan Orange $\mathrm{G}$ with bacterial CotA-laccase. J Biotechnol 2009, 139(1):68-77.

19. Singh G, Capalash N, Goel R, Sharma P: A pH-stable laccase from alkalitolerant g-proteobacterium JB: Purification, characterization and indigo carmine degradation. Enzyme Microb Technol 2007, 41(6-7):794-799.

20. Williams GJ, Nelson AS, Berry A: Directed evolution of enzymes for biocatalysis and the life sciences. Cell Mol Life Sci 2004, 61(24):3034-3046.

21. Wells A, Teria M, Eve T: Green oxidations with laccase-mediator systems. Biochem Soc Trans 2006, 34:304-308.

22. Enguita FJ, Martins LO, Henriques AO, Carrondo MA: Crystal structure of a bacterial endospore coat component - A laccase with enhanced thermostability properties. J Biol Chem 2003, 278(21):19416-19425.

23. Hullo MF, Moszer I, Danchin A, Martin-Verstraete I: CotA of Bacillus subtilis is a copper-dependent laccase. J Bacteriol 2001, 183(18):5426-5430.

24. Sakurai T, Kataoka K: Basic and applied features of multicopper oxidases, CueO, bilirubin oxidase, and laccase. Chem Rec 2007, 7(4):220-229.
25. Koschorreck K, Richter SM, Ene AB, Roduner E, Schmid RD, Urlacher VB: Cloning and characterization of a new laccase from Bacillus licheniformis catalyzing dimerization of phenolic acids. Appl Microbiol Biotechnol 2008, 79(2):217-224

26. Durao $P$, Chen $Z$, Fernandes AT, Hildebrandt $P$, Murgida DH, Todorovic $S$, Pereira MM, Melo EP, Martins LO: Copper incorporation into recombinant CotA laccase from Bacillus subtilis: characterization of fully copper loaded enzymes. J Biol Inorg Chem 2008, 13(2):183-193.

27. Bradford MM: Rapid and sensitive method for quantitation of microgram quantities of protein utilizing principle of protein-dye binding. Anal Biochem 1976, 72(1-2):248-254.

28. Martins LO, Soares CM, Pereira MM, Teixeira M, Costa T, Jones GH, Henriques AO: Molecular and biochemical characterization of a highly stable bacterial laccase that occurs as a structural component of the Bacillus subtilis endospore coat. J Biol Chem 2002, 277(21):18849-18859.

29. Enguita FJ, Marcal D, Martins LO, Grenha R, Henriques AO, Lindley PF, Carrondo MA: Substrate and doxygen binding to the endospore coat laccase from Bacillus subtilis. J Biol Chem 2004, 279(22):23472-23476.

30. Rosconi F, Fraguas LF, Martinez-Drets G, Castro-Sowinski S: Purification and characterization of a periplasmic laccase produced by Sinorhizobium meliloti. Enzyme Microb Technol 2005, 36(5-6):800-807.

31. Kandelbauer A, Kessler W, Kessler RW: Online UV-visible spectroscopy and multivariate curve resolution as powerful tool for model-free investigation of laccase-catalysed oxidation. Anal Bioanal Chem 2008, 390(5):1303-1315.

32. Podgornik H, Poljansek I, Perdih A: Transformation of Indigo carmine by Phanerochaete chrysosporium ligninolytic enzymes. Enzyme Microb Technol 2001, 29(2-3):166-172.

33. Claus H: Laccases and their occurrence in prokaryotes. Arch Microbiol 2003, 179(3):145-150

34. Xu F, Shin WS, Brown SH, Wahleithner JA, Sundaram UM, Solomon El: A study of a series of recombinant fungal laccases and bilirubin oxidase that exhibit significant differences in redox potential, substrate specificity, and stability. Biochim Biophys Acta: Proteins Proteomics 1996 1292(2):303-311

35. Hilden K, Hakala TK, Maijala P, Lundell TK, Hatakka A: Novel thermotolerant laccases produced by the white-rot fungus Physisporinus rivulosus. Appl Microbiol Biotechnol 2007, 77(2):301-309.

36. Rodakiewicz-Nowak J, Kasture SM, Dudek B, Haber J: Effect of various water-miscible solvents on enzymatic activity of fungal laccases. $J \mathrm{Mol}$ Catal B: Enzym 2000, 11(1):1-11.

37. Tominaga J, Michizoe J, Kamiya N, Ichinose H, Maruyama T, Goto M: Factors affecting the oxidative activity of laccase towards biphenyl derivatives in homogeneous aqueous-organic systems. J Biosci Bioeng 2004, 98(1):14-19.

38. Smirnov SA, Koroleva OV, Gavrilova VP, Belova AB, Klyachko NL: Laccases from basidiomycetes: Physicochemical characteristics and substrate specificity towards methoxyphenolic compounds. Biochemistry (Moscow) 2001, 66(7):774-779.

39. Garzillo AMV, Colao MC, Caruso C, Caporale C, Celletti D, Buonocore V: Laccase from the white-rot fungus Trametes trogii. Appl Microbiol Biotechnol 1998, 49(5):545-551.

40. Molina-Guijarro JM, Perez J, Munoz-Dorado J, Guillen F, Moya R, Hernandez M, Arias ME: Detoxification of azo dyes by a novel $\mathrm{pH}$ versatile, salt-resistant laccase from Streptomyces ipomoea. Int Microbiol 2009, 12(1):13-21.

41. Youn HD, Kim KJ, Maeng JS, Han YH, Jeong IB, Jeong GJ, Kang SO, Hah YC: Single-electron transfer by an extracellular laccase from the white-rot fungus Pleurotus ostreatus. Microbiology 1995, 141:393-398.

42. Koschorreck K, Schmid RD, Urlacher VB: Improving the functional expression of a Bacillus licheniformis laccase by random and site-directed mutagenesis. BMC Biotechnol 2009, 9:12.

doi:10.1186/1472-6750-11-9

Cite this article as: Reiss et al: Bacillus pumilus laccase: a heat stable enzyme with a wide substrate spectrum. BMC Biotechnology 2011 11:9. 